University of Nebraska - Lincoln

DigitalCommons@University of Nebraska - Lincoln

Faculty Publications from the Harold W. Manter Laboratory of Parasitology

1961

Notes on the Collared Pika, Ochotona collaris (Nelson), in Alaska

Robert L. Rausch

University of Washington, rausch@uw.edu

Follow this and additional works at: https://digitalcommons.unl.edu/parasitologyfacpubs

Part of the Parasitology Commons

Rausch, Robert L., "Notes on the Collared Pika, Ochotona collaris (Nelson), in Alaska" (1961). Faculty Publications from the Harold W. Manter Laboratory of Parasitology. 345.

https://digitalcommons.unl.edu/parasitologyfacpubs/345

This Article is brought to you for free and open access by the Parasitology, Harold W. Manter Laboratory of at DigitalCommons@University of Nebraska - Lincoln. It has been accepted for inclusion in Faculty Publications from the Harold W. Manter Laboratory of Parasitology by an authorized administrator of DigitalCommons@University of Nebraska - Lincoln. 


\section{NOTES ON THE COLLARED PIKA, OCHOTONA COLLARIS (NELSON), IN ALASKA}

\section{ROBERT L. RAUSCH}

Maps showing the geographic range of the collared pika, Ochotona collaris (Nelson), have been published recently by Hall (1951) and by Hall and Kelson (1959). According to these, this mammal occurs in the mountains between the Tanana and Yukon Rivers, and in the Alaska Range as far west as Mt. McKinley. A specimen from the summit of the Chugach Mountains (Baker, 1951) was not included on the aforementioned maps. Osgood (1904) referred to two specimens collected by C. L. McKay in the Chigmit Mountains, east of Lake Clark at the base of the Alaska Peninsula, and also mentioned a sight record for Keejik Mountain by Lake Clark.

During the years 1950-1961, I have collected 73 collared pikas in Alaska. The majority (66) was taken in the Talkeetna Mountains, in the general vicinity of Willow Pass; the remainder was from the following localities: Isabella Pass, Alaska Range (1); unnamed lake (lat. $62^{\circ} 48^{\prime} 20^{\prime \prime} \mathrm{N}$., long. $146^{\circ} 41^{\prime} 30^{\prime \prime}$ W.) north of Lake Louise (2); Eklutna Lake (1) and near the head of Eagle River (1), Chugach Mountains; White Mountain, near Na-

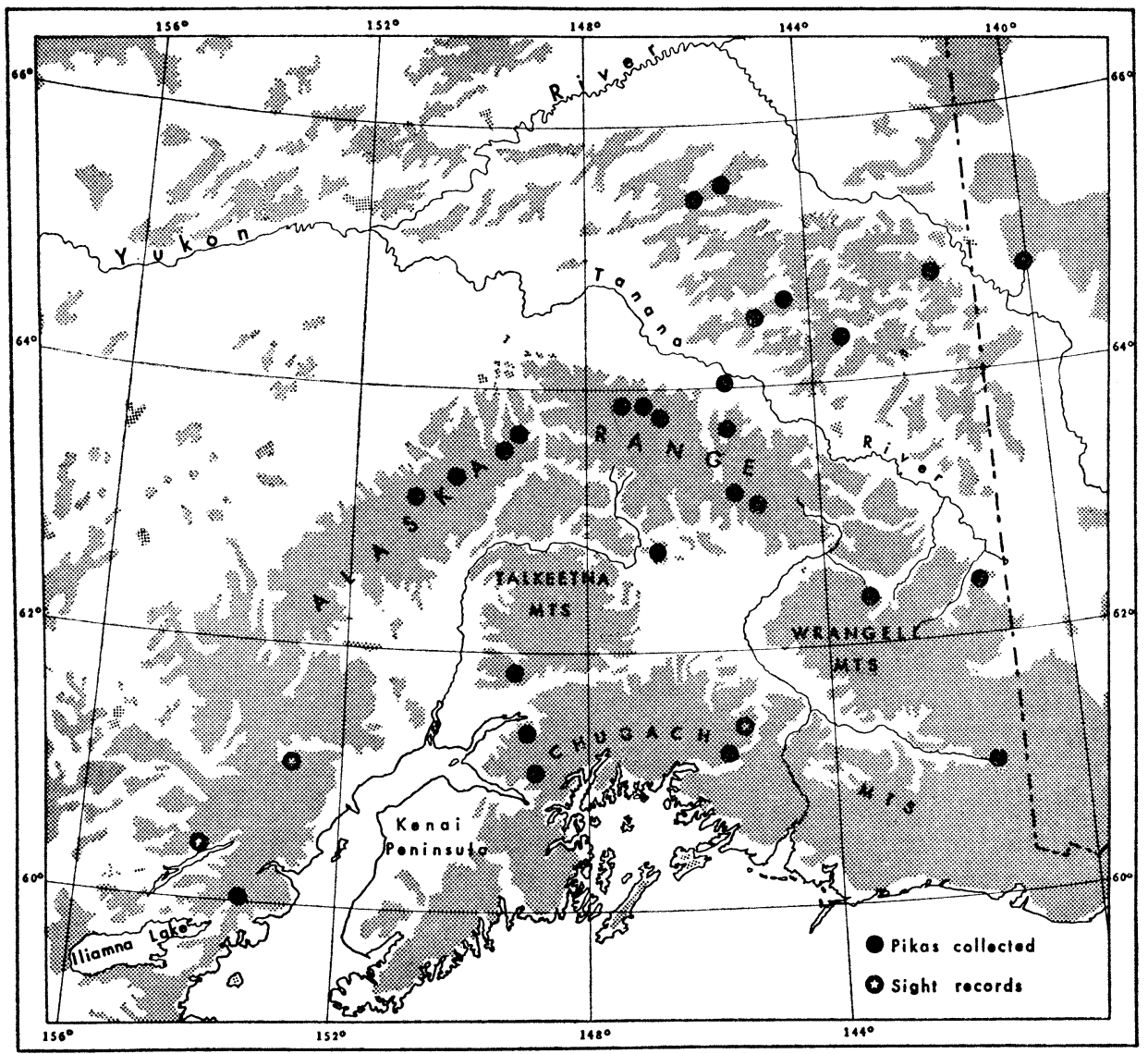

Figure 1. Map of southeastern quadrant of Alaska, with records of occurrence of the collared pika (published and original data included). Mountain ranges are shaded to timberline (after Sigafoos, 1958). 
besna, Wrangell Mountains (2). I also saw a pika, not collected, along the Richardson Highway 45 miles north of Valdez, in the Chugach Mountains. Mr. Ronald O. Skoog, Alaska Department of Fish and Game, (personal communication) observed pikas at the west end of Chakachamna Lake, north of Lake Clark, on July 3-4, 1961.

The above records together with those previously published seem to permit a comparatively accurate delineation of the geographic range of the collared pika west of about long. $140^{\circ} \mathrm{W}$. (Figure 1). This mammal may be expected to occur in suitable habitat in the mountains between the Yukon and Tanana Rivers (see Libby, 1958), throughout the Wrangell, Chugach, and Talkeetna Mountains, and south in the Alaska Range to the Chigmit Mountains. The collared pika has not been recorded from the mountains on the Kenai Peninsula. Portage Pass, on the isthmus separating the Peninsula from the adjacent mainland, may be a natural barrier which the pika, and evidently the arctic ground squirrel, Citellus undulatus (Pallas), as well, have not been able thus far to cross. Little is known about the movements of the collared pika away from the rock-slides it chaarcteristically inhabits. On September 12, 1954, at the locality north of Lake Louise, I found pikas in a forested valley (white spruce-birch-willow) more than 200 yards from the nearest talus, and their burrows were beneath scattered rocks among the trees. Anthony (1923) reported that O. princeps (Richardson) may migrate up to several miles through dense forest.

All but one of the 73 pikas mentioned above were collected during the period May 30-October 2. Forty-five were males, 26 were females, and the sex of two was not recorded. A female killed in the Talkeetna Mountains on May 30 contained 3 embryos; the latest pregnancy recorded was on June 13 at the same locality. The latter animal was also lactating, and this provided the only indication that more than one litter may be born per year. The earliest observed emergence of young was June 19, when a female weighing 77.5 grams was collected.

Three pikas were seen in a rock-slide above Eklutna Lake on November 10,1961 , and one was collected. The ambient temperature at the time was about $10^{\circ} \mathrm{F}$., and the depth of snow was insufficient to cover the rocks. Dixon (1938) reported that Charles Sheldon found pikas active at Mt. McKinley on December 26, 1907, at a temperature of $-31^{\circ} \mathrm{F}$. The depth of snow is usually too great to permit winter observations on this mammal.

Howell (1924) stated that the collared pika seems to have only one annual molt. My findings are in agreement with Howell's, since only the specimen taken on November 10 had completed the molt.

The diet of the collared pika in Alaska has evidently not been described in detail. At the southern limits of the Talkeetna Mountains, where the flora has a large component of coastal species, a hay-pile examined on October 2 contained the following: Cystopteris fragilis (L.) Bernh.; Lycopodium sp.; Carex sp.; Sanguisorba sitchensis C. A. Meyer; Cassiope Stelleriana (Pall.); Luetkea pectinata (Pursh) Kuntze (entire stalks with flowers); Epilobium latifolium L. (comprising about 60 per cent of the total volume). At the locality north of Lake Louise, a hay-pile on September 10 contained: Ledum palustre ssp. decumbens (Ait.) Hult.; Vaccinium Vitis-idaea L. (with berries); Empetrum nigrum L. (with berries); Salix sp.; leaves of Betula kenaica Evans hybridized with a dwarf species of Betula. The observations suggest that the pikas utilize whatever plants are available near the rockslides.

Feces of ermine, Mustela erminea L., have often been noted on the haypiles. On July 11, 1954, I watched an ermine carrying a pika across a rock- 
slide in the Talkeetna Mountains. The ermine was collected and found to be a female weighing 109.6 grams; the pika it had killed (as indicated by tooth-marks and hemorrhage at the base of the skull) weighed 118.6 grams. The ermine appears to be an important predator on pikas in south-central Alaska, according to evidence of its presence in slides inhabited by the latter.

The striated muscles of collared pikas, particularly in the Talkeetna Mountains, often contain Sarcocystis sp. Parasitic helminths found in these pikas have been reported elsewhere (Akhtar, 1956; 1958; Rausch, 1960), and their fleas have been discussed by Holland (1958).

-Arctic Health Research Center, Public Health Service, U. S. Department of Health, Education, and Welfare, Anchorage, Alaska

\section{LITERATURE CITED}

AKHTAR, S. A. 1956. On the nematodes (Family: Oxyuridae Cobb., Sub-family: Labiostominae n. subf.) parasitic in the pika of Alaska-I. Pakistan J. Sci. Res. 8:133-139.

AKHTAR, S. A. 1958. On the nematodes (Family: Oxyuridae Cobb., Sub-family: Labiostominae n. subf.) parasitic in the pika of Alaska-II. Pakistan J. Sci. Res. 10:56-62.

ANTHONY, A. W. 1923. Periodical emigrations of mammals. J. Mammal. 4:60-61.

BAKER, R. H. 1951. Mammals taken along the Alaska Highway. Univ. Kansas Publ., Mus. Nat. Hist. 5:87-117.

DIXON, J. S. 1938. Birds and mammals of Mount McKinley National Park, Alaska. Fauna Series No. 3, Nat. Park Svc. U. S. Govt. Printing Office, Wash., D.C. 236 pp.

HALL, E. R. 1951. A synopsis of the North American Lagomorpha. Univ. Kansas Publ., Mus. Nat. Hist. 5:119-202.

HALL, E. R., and Kelson, K. R. 1959. The mammals of North America. Vol. I. Ronald Press. New York. $546 \mathrm{pp}$.

HOLLAND, G. P. 1958. Distribution patterns of northern fleas (Siphonaptera). Proc. 10th Int'l. Congr. Entomology, Vol. I. pp. 645-658.

HOWELL, A. H. 1924. Revision of the American pikas. North Amer. Fauna, No. 47. U. S. Dept. Agric. Govt. Printing Office, Wash., D.C. 57 pp.

LIBBY, W. L. 1958. Records of the pika in the Tanana Hills, Alaska. J. Mammal. 39:448-449.

OSGOOD, W. H. 1904. A biological reconnaissance of the base of the Alaska Peninsula. North Amer. Fauna, No. 24. U. S. Dept. Agric. Govt. Printing Office, Wash., D.C. $86 \mathrm{pp}$.

RAUSCH, R. 1960. Studies on the helminth fauna of Alaska. XXXVII. Description of Schizorchis caballerio $\mathrm{n}$. sp. (Cestoda: Anoplocephalidae), with notes on other parasites of Ochotona. Libro Homenaje Dr. Edu. Caballero y C. Mexico, D. F. $594 \mathrm{pp}$.

SIGAFOOS, R. S. 1958. Vegetation of northwestern North America, as an aid in interpretation of geologic data. Geological Surv. Bull. 1061-E. U. S. Dept. Int. Govt. Printing Office, Wash., D.C. pp. 165-185.

\section{Another Record of the White-Throated Sparrow for Eastern Washington}

There are few records of the White-throated Sparrow (Zono trichia albicollis) for eastern Washington. Therefore it is of interest to note that Jim Acton and several other members of the Spokane Bird Club reported observing one at Indian Canyon in northwest Spokane on September 29, 1961. The following day, September 30, I collected the specimen, which was an immature male, and made it up as a study skin. This is the first record of this bird in the Spokane area.-LynN D. LAFAve, Spokane, Washington, January 12, 1962. 